\title{
PENGARUH UKURAN PERUSAHAAN, PROFITABILITAS, DAN LEVERAGE TERHADAP KEBIJAKAN DIVIDEN PADA PERUSAHAAN MANUFAKTUR
}

\section{Ni Wayan Indah Paramyta Agustino ${ }^{1}$ Sayu Ketut Sutrisna Dewi ${ }^{2}$}

\author{
${ }^{1}$ Fakultas Ekonomi dan Bisnis Universitas Udayana (Unud), Bali, Indonesia
} E-mail: iinp.a@yahoo.com

\begin{abstract}
ABSTRAK
Penelitian ini bertujuan untuk menguji pengaruh ukuran perusahaan, profitabilitas, dan leverage terhadap kebijakan dividen. Penelitian ini dilakukan pada Perusahaan Manufaktur yang terdaftar di Bursa Efek Indonesia (BEI). Pengambilan sampel dilakukan dengan menggunakan sampling jenuh atau sensus dan diperoleh sebanyak 47 perusahaan manufaktur yang membayarkan dividen dan menghasilkan profit di BEI selama tahun 2014-2016. Teknik analisis yang digunakan adalah analisis regresi linier berganda. Hasil penelitian menunjukkan bahwa ukuran perusahaan dan profitabilitas berpengaruh terhadap kebijakan dividen, sedangkan leverage tidak berpengaruh.
\end{abstract}

Kata Kunci : kebijakan dividen, profitabilitas, ukuran perusahaan, leverage

\section{ABSTRACT}

This study aims to examine the effect of company size, profitability, and leverage on dividend policy. This research was conducted at Manufacturing Companies listed on the Indonesia Stock Exchange (IDX). Sampling is done by using saturated sampling or census and obtained as many as 47 manufacturing companies that paid dividends and produced profits on the IDX during 2014-2016. The analysis technique used is multiple linear regression analysis. The results showed that company size and profitability influence dividend policy, while leverage has no affect.

Keywords: dividend policy, profitability, company size, leverage 
Ni Wayan Indah Paramyta Agustino, Pengaruh Ukuran Perusahaan...

\section{PENDAHULUAN}

Salah satu tujuan utama manajemen keuangan adalah untuk memaksimalkan kesejahteraan shareholder dengan cara memaksimalkan nilai perusahaan. Nilai perusahaan merupakan kondisi yang telah dicapai oleh suatu perusahaan sebagai gambaran dari kepercayaan masyarakat terhadap perusahaan setelah melalui suatu proses kegiatan selama beberapa tahun, yaitu sejak perusahaan tersebut didirikan sampai dengan saat ini (Noerirawan, 2012). Manajer keuangan dituntut mampu mengambil keputusan keuangan perusahaan yang dapat meningkatkan nilai perusahaan.

Terdapat 3 keputusan manajemen keuangan yaitu: (1) Keputusan investasi berkaitan dengan manajer harus mengalokasin dana ke dalam bentuk - bentuk investasi yang akan menguntungkan di masa yang akan datang; (2) Keputusan pendanaan sering disebut juga sebagai kebijakan capital structure atau struktur modal. Dalam hal ini, manajer keuangan dituntut untuk memperoleh dana yang ekonomis yang akan dibelanjakan untuk usaha - usaha perusahaan dan investasinya; (3) Kebijakan dividen, merupakan kebijakan yang membagikan sebagian keuntungan perusahaan kepada para pemegang saham. Dividen juga menentukan porsi laba yang akan dibagikan dan juga porsi laba yang akan disimpan sebagai laba ditahan. Kebijakan ini juga dapat mempengaruhi financial structure maupun capital structure (Sutrisno, 2012:5).

Sebagian besar aktivitas suatu perusahaan adalah kegiatan investasi. Dalam menginvestasikan sejumlah dana, hal utama yang diharapkan seorang investor adalah adanya keuntungan yang akan diperoleh di masa datang. Untuk itu investor perlu melakukan analisis untuk menentukan dasar yang dapat digunakan dalam 
menilai kelayakan saham suatu perusahaan untuk dijadikan sebagai salah satu alternatif investasi (Parica dkk., 2013).

Investor dalam menginvestasikan dananya ke dalam instrument saham tentunya menginginkan return yang tinggi. Return dari saham dapat diperoleh dari capital gain maupun dari dividen. Jadi tujuan investor melakukan investasi saham adalah (1) keuntungan yang diperoleh dari selisih pergerakan harga saham pada saat membeli dan saat menjual (capital gain); (2) keuntungan yang didapat oleh investor diperoleh dari pembagian dividen sesuai jumlah lembar yang dimiliki oleh investor.

Dividen merupakan salah satu kebijakan yang penting dalam perusahaan, karena menyangkut pemegang saham yang merupakan sumber modal dari perusahaan tersebut. Perusahaan yang memiliki kinerja yang baik dan menghasilkan keuntungan akan memiliki kesempatan untuk menggunakan keuntungan tersebut sebagai laba ditahan atau dividen. Keputusan pembayaran dividen juga akan mencerminkan kinerja perusahaan yang baik dan memenuhi harapan dari para pemegang saham.

Kebijakan dividen sering menimbulkan konflik kepentingan antara pihak manajemen perusahaan dengan pihak pemegang saham. Pihak manajemen perusahaan tentunya mengharapkan laba yang didapatkan akan lebih baik digunakan untuk membiayai proyek dimasa depan atau digunakan untuk investasi lainnya, sedangkan bagi pemegang saham laba yang dihasilkan oleh perusahaan diharapkan dibagikan sebagai dividen.

Menurut Wiagustini (2014:294), terdapat beberapa faktor yang mempengaruhi kebijakan dividen yaitu sebagai berikut: (1) Posisi kas atau 
likuiditas mempengaruhi kemampuan perusahaan untuk membayarkan dividen. Bagi perusahaan yang memiliki laba ditahan yang cukup, tetapi manajemen memutuskan untuk menginvestasikan ke dalam aktiva riil, maka perusahaan tidak dapat membayar dividen dalam bentuk kas; (2) Kebutuhan pembayaran kembali utang perusahaan juga berpengaruh terhadap kemampuan perusahaan untuk membayar dividen. Adanya batasan dalam perjanjian pinjaman kepada kreditur hanya dapat dilakukan setelah laba tersedia bagi pemegang saham dikurangi dengan angsuran pinjaman atau apabila modal kerja mencapai tingkat tertentu; (3) Tingkat ekspansi yang tinggi membutuhkan dana yang besar, sehingga laba yang diperoleh lebih baik ditahan. Stabilitas earning memungkinkan perusahaan dalam mempertahankan payout ratio yang tinggi; (4) Akses perusahaan di pasar modal berpengaruh pula terhadap kebijakan dividen. Bagi perusahaan yang sudah established maka akan lebih mudah bagi perusahaan tersebut untuk mempertahankan payout ratio yang lebih tinggi dibandingkan dengan perusahaan yang kecil; (5) Posisi pemegang saham dalam kelompok pajak juga berpengaruh terhadap kebijakan dividen. Perusahaan yang dimiliki oleh investor yang kecil akan cenderung memiliki payout ratio yang tinggi.

Kebijakan dividen merupakan keputusan untuk menentukan berapa banyak dividen yang harus dibagikan kepada para pemegang saham. Kebijakan ini bermula dari bagaimana perlakuan manajemen terhadap keuntungan yang diperoleh perusahaan yang pada umumnya sebagian dari penghasilan bersih setelah pajak (EAT/Earning After Tax) dibagikan kepada para investor dalam bentuk dividen dan sebagian lagi diinvestasikan kembali keperusahaan dalam bentuk laba ditahan. 
Persentase dari pendapatan yang akan dibayarkan kepada pemegang saham sebagai cash dividend (laba yang dibagikan dalam bentuk uang tunai) disebut Dividend Payout Ratio atau selanjutnya disingkat DPR (Riyanto, 2001:266).

DPR adalah perbandingan antara dividen yang dibayarkan dengan laba bersih yang didapatkan dan biasanya disajikan dalam bentuk persentase. Semakin tinggi DPR akan semakin menguntungkan pihak investor, tetapi bagi perusahaan akan memperkecil laba ditahan yang dapat digunakan untuk mengembangkan perusahaan (internal financing). Sebaliknya apabila DPR semakin kecil, maka akan bagian keuntungan yang diterima pemegang saham (investor) akan semakin kecil, tetapi internal financing perusahaan semakin kuat (Parica dkk., 2013).

Menurut Handayani dan Hadinugroho (2009:66) ukuran perusahaan adalah skala besar kecilnya perusahaan, suatu perusahaan besar yang sudah mapan akan memiliki akses mudah menuju pasar modal. Kemudahan ini cukup berarti untuk fleksibilitas dan kemampuannya untuk memperoleh dana yang lebih besar, sehingga perusahaan mampu memiliki DPR lebih tinggi dari pada perusahaan kecil. Jadi semakin besar ukuran perusahaan, maka dividen yang dibagikan juga cenderung semakin besar. Variabel ukuran perusahaan (size) dinyatakan berpengaruh negatif terhadap kebijakan dividen (dividend payout ratio) pada penelitian Setiawan (2013), Jahanzeb (2016), Khalid (2015), Shubiri (2012) dan Banerjee (2016). Berbeda dengan hasil penelitian Kangarlouei (2014), Najjar (2009), Jape (2016), Yarram (2014) dan Nixon (2012) yang menyatakan bahwa ukuran perusahaan (size) berpengaruh positif terhadap kebijakan dividen (DPR). 
Profitabilitas merupakan kemampuan perusahaan memperoleh laba dalam hubungannya dengan penjualan, total asset maupun modal sendiri. Menurut Hanafi dan Halim (2005:85) rasio profitabilitas sangat bermanfaat bagi kelangsungan perusahaan karena dapat membantu perusahaan untuk mengetahui kontribusi keuntungan perusahaan dalam jangka pendek atau jangka panjang. Oleh karena itu dividen diambil dari keuntungan bersih yang diperoleh perusahaan, maka keuntungan tersebut akan mempengaruhi besarnya dividend payout ratio. Semakin besar keuntungan yang diperoleh, maka akan semakin besar pula kemampuan perusahaan untuk membayar dividen. Variabel profitabilitas yang diukur dengan rasio return on asset (ROA) dinyatakan berpengaruh positif dan signifikan terhadap kebijakan dividen pada penelitian Setiawan dan Phua (2013), Ali (2015), Jahanzeb (2016), Kangarlouei (2014), Najjar (2009), Yarram (2014) dan Nixon (2012). Berbeda dengan hasil penelitian Banerjee (2016) yang menyatakan bahwa profitabilitas yang diukur dengan ROA berpengarug negatif dan tidak signifikan terhadap kebijakan dividen (DPR).

Leverage mencerminkan kemampuan perusahaan dalam memenuhi seluruh kewajibannya yang ditunjukkan oleh beberapa bagian modal sendiri yang digunakan untuk membayar hutang (Rodoni dan Ali, 2010:123). Leverage biasanya diukur dengan Debt to Equity Ratio (DER). Variabel leverage dinyatakan berpengaruh negatif terhadap kebijakan dividen pada penelitian Kangarloue (2014), Sari (2015), dan Mawarni (2014). Berbeda dengan hasil penelitian Arilaha (2009) dan Tahir (2015) yang menyataan bahwa leverage berpengaruh negatif tetapi tidak signifikan terhadap kebijakan dividen. 
Sembilan sektor di BEI salah satunya sektor manufaktur. Perusahaan manufaktur adalah perusahaan yang mengolah barang mentah menjadi barang setengah jadi atau barang jadi sehingga menambah nilai dari barang tersebut. Sektor manufaktur memegang posisi dominan dalam perkembangan perekonomian di Indonesia, karena berhubungan langsung dengan daya beli masyarakat sehari - hari (Wijanti dan Sedana, 2013). Perusahaan manufaktur merupakan jenis usaha yang bergerak di sektor riil dan memiliki jumlah perusahaan paling banyak dibandingkan jenis usaha lain. Kinerja perusahaan manufaktur yang baik akan meningkatkan kepercayaan masyarakat terhadap perusahaan tersebut, sebaliknya apabila kinerja perusahaan manufaktur kurang optimal, maka tingkat kepercayaan masyarakat terhadap perusahaan tersebut akan menurun.

Menurut Ikhsan (2009:91), analisis rasio keuangan mengungkapkan hubungan keuangan secara numerik diantara pelaporan dalam laporan keuangan dan menggunakannya untuk membandingkan secara rasional periode saat ini terhadap periode sebelumnya. Analisis rasio dapat membimbing investor membuat keputusan atau pertimbangan tentang apa yang akan dicapai oleh perusahaan dan bagaimana prospek yang akan dihadapi di masa depan.

Variabel ukuran perusahaan, profitabilitas dan leverage mempunyai hubungan yang dapat mempengaruhi kebijakan dividen. Ukuran perusahaan merupakan skala besar kecilnya perusahaan, suatu perusahaan besar yang sudah memiliki akses menuju pasar modal. Semakin besar ukuran perusahaan maka dividen yang dibagikan semakin besar. Profitabilitas merupakan kemampuan perusahaan memperoleh laba dalam hubungannya dengan penjualan total asset 
maupun modal sendiri. Semakin besar keuntungan yang diperoleh maka akan semakin besar pula kemampuan perusahaan untuk membayar dividen. Leverage merupakan rasio yang digunakan untuk mengetahui seberapa besar kemampuan perusahaan dalam membayarkan seluruh kewajibannya (baik kewajiban jangka panjang maupun jangka pendek).

Penelitian ini bertujuan melakukan kajian empiris terhadap faktor - faktor yang mempengaruhi kebijakan dividen perusahaan, khususnya perusahaan manufaktur yang terdaftar di Bursa Efek Indonesia (BEI). Berdasarkan beberapa hasil penelitian terdahulu yang telah dijelaskan, variabel - variabel tersebut belum memberikan hasil yang konsisten sehingga perlu diuji kembali untuk memperkuat temuan - temuan sebelumnya. Dalam penelitian ini menggunakan tiga variabel bebas yaitu ukuran perusahaan, profitabilitas, dan leverage.

Kebijakan dividen merupakan rencana tindakan yang harus diikuti dalam membuat keputusan dividen. Kebijakan dividen harus diformulasikan untuk dua dasar tujuan dengan memperhatikan maksimalisasi kekayaan dari pemilik perusahaan dan pembiayaan yang cukup. Kedua tujuan tersebut saling berhubungan dan harus memenuhi berbagai faktor hukum, perjanjian, internal, pertumbuhan, hubungan dengan xpemilik, hubungan dengan pasar yang membatasi alternatif kebijakan (Sundjaja dan Barlin, 2010:388).

Bambang Riyanto (2001: 281) mendefinisikan kebijakan dividen sebagai "politik yang bersangkutan dengan penentuan pembagian pendapatan (earning) antara penggunaan pendapatan untuk dibayarkan kepada para pemegang saham sebagai dividen atau untuk digunakan di dalam perusahaan (laba ditahan). 
Menurut Handayani dan Hadinugroho (2009:66) ukuran perusahaan adalah skala besar kecilnya perusahaan ditentukan oleh total aset. Besar kecilnya perusahaan merupakan salah satu faktor yang dapat dipertimbangkan investor dalam melakukan investasi. Perusahaan yang memiliki ukuran besar akan lebih mudah memasuki pasar modal sehingga dengan kesempatan ini perusahaan membayar dividen besar kepada pemegang saham. Sementara perusahaan yang baru dan masih kecil akan mengalami banyak kesulitan untuk memiliki akses ke pasar modal sehinnga kemampuannya untuk mendapatkan modal dan memperoleh pinjaman dari pasar modal juga terbatas. Oleh karena itu maka mereka cenderung untuk menahan labanya guna membiayai operasinya, dan ini berarti dividen yang akan diterima oleh pemegang saham akan semakin kecil. 1) Dividend irrelevance theory, adalah suatu teori yang menyatakan bahwa kebijakan dividen tidak mempunyai pengaruh, baik terhadap nilai perusahaan maupun biaya modalnya. Teori ini mengikuti pendapat Modigliani dan Miller (MM) yang menyatakan bahwa nilai suatu perusahaan tidak ditentukan oleh besar kecilnya DPR tetapi ditentukan oleh laba bersih sebelum pajak (EBIT) dan risiko bisnis. Dengan demikian kebijakan dividen sebenarnya tidak relevan untuk dipersoalkan. 2) Bird in the hand Theory. Tingkat keuntungan yang disyaratkan akan naik apabila pembagian dividen dikurangi karena investor lebih yakin terhadap penerimaan dividen daripada kenaikan nilai modal (capital gain) yang akan dihasilkan dari laba ditahan. Pendapat Gordon dan Litner (1956) oleh MM diberi nama bird in the hand fallacy. Gordon dan Litner beranggapan investor memandang bahwa satu burung di tangan lebih berharga daripada seribu burung di udara. Namun, MM berpendapat bahwa 
tidak semua investor berkepentingan untuk menginvestasikan kembali dividen mereka di perusahaan yang sama dengan memiliki resiko yang sama, oleh sebab itu tingkat resiko pendapatan mereka di masa yang akan datang bukannya ditentukan oleh DPR tetapi ditentukan oleh tingkat resiko investasi baru. 3) Tax preference theory. Adalah suatu teori yang menyatakan bahwa karena adanya pajak terhadap keuntungan dividen dan capital gains maka para investor lebih menyukai capital gains karena dapat menunda pembayaran pajak.

Kebijakan Dividen Rasio Pembayaran Konstan. Kebijakan ini didasarkan dengan persentase tertentu dari pendapatan. Dimana rasio pembayaran dividen adalah persentase dari setiap rupiah yang dihasilkan dibagikan kepada pemilik dalam bentuk tunai, dihitung dengan membagi dividen kas per saham dengan laba per saham. Masalah dengan kebijakan ini adalah jika pendapatan perusahaan turun atau rugi pada suatu periode tertentu, maka dividen menjadi rendah atau tidak ada. Karena dividen merupakan indikator dari kondisi perusahaan yang akan datang maka mungkin dapat berdampak buruk terhadap harga saham.

Kebijakan Dividen Teratur. Kebijakan dividen yang didasarkan atas pembayaran dividen dengan rupiah yang tetap dalam setiap periode. Kebijakan yang teratur seringkali digunakan dalam memakai target rasio pembayaran dividen. Dimana target rasio pembayaran dividen adalah kebijakan dimana perusahaan mencoba membayar dividen dalam persentase tertentu seperti dividen yang dinyatakan dalam rupiah serta disesuaikan terhadap target pembayaran yang membuktikan terjadinya peningkatan hasil. Kebijakan Dividen Rendah Teratur dan Ditambah Ekstra. Kebijakan dividen yang didasarkan pembayaran dividen rendah 
yang teratur, ditambah dengan dividen ekstra jika ada jaminan pendapatan. Jika pendapatannya lebih tinggi dari biasanya pada periode tertentu, perusahaan boleh membayar tambahan dividen yang disebut dividen ekstra.

Menurut Kasmir (2009:162), rasio profitabilitas merupakan rasio untuk menilai kemampuan perusahaan dalam mencari keuntungan atau laba dalam suatu periode tertentu. Rasio ini juga memberikan ukuran tingkat efektivitas manajemen suatu perusahaan. Hal ini ditunjukkan oleh laba yang dihasilkan dari penjualan dan pendapatan investasi. Dalam penelitian ini rasio yang digunakan yaitu Return On Assets (ROA) adalah perbandingan laba bersih dengan total aktiva dan dinyatakan dalam persentase. Rasio ini menunjukkan seberapa besar persentase perusahaan untuk menghasilkan laba dari aset yang digunakan dari setiap penjualan. Semakin besar rasio ini dianggap semakin baik kemajuan perusahaan untuk mendapatkan laba yang tinggi.

Menurut Kasmir (2009:158) leverage merupakan rasio yang digunakan untuk mengetahui seberapa besar kemampuan perusahaan dalam membayarkan seluruh kewajibannya (baik kewajiban jangka pendek maupun jangka panjang). Jenis rasio hutang (leverage ratio) dalam penelitian ini adalah debt to equity ratio atau disingkat DER. DER merupakan rasio yang digunakan untuk menilai hutang dengan ekuitas. Rasio ini menggambarkan perbandingan hutang dan ekuitas dalam pendanaan perusahaan dan menunjukkan kemampuan modal sendiri perusahaan tersebut untuk memenuhi seluruh kewajibannya. 
Ni Wayan Indah Paramyta Agustino, Pengaruh Ukuran Perusahaan...

Hasil penelitian Handayani dan Hadinugroho (2009) menunjukkan bahwa size berpengaruh signifikan terhadap kebijakan dividen karena perusahaan yang memiliki ukuran yang besar akan lebih mudah memasuki pasar modal sehingga dengan kesempatan ini perusahaan membayar dividen dengan jumlah besar kepada pemegang saham. Sementara perusahaan yang baru dan yang masih kecil akan mengalami banyak kesulitan untuk memiliki akses ke pasar modal, sehingga semakin besar ukuran perusahaan semakin mudah untuk mendapatkan modal eksternal dalam jumlah yang lebih besar terutama dari hutang. Ukuran perusahaan merupakan simbol ukuran perusahaan yang berhubungan dengan peluang dan kemampuan untuk masuk ke pasar modal dan jenis pembiayaan eksternal lainnya yang menunjukkan kemampuan meminjam. Hal ini menunjukkaan hubungan, bahwa semakin besar ukuran perusahaan maka semakin besar pula dividen yang akan dibagikan. Pernyataan tersebut didukung oleh penelitian Kangarlouei (2014), Najjar (2009), Jape (2016), Yarram (2014), dan Nixon (2012) yang menunjukkan bahwa ukuran perusahaan berpengaruh positif signifikan terhadap kebijakan dividen.

$\mathrm{H}_{1}$ : Ukuran Perusahaan berpengaruh positif signifikan terhadap kebijakan dividen pada perusahaan manufaktur yang terdaftar di Bursa Efek Indonesia.

Menurut Rodoni dan Ali (2010:123) profitabilitas adalah kemampuan perusahaan memperoleh laba dalam hubungannya dengan penjualan, total aset maupun modal sendiri. Dengan demikian bagi investor jangka panjang akan sangat berkepentingan dengan analisis profitabilitas ini misalnya bagi pemegang saham akan melihat keuntungan yang benar-benar akan diterima dalam bentuk dividen. Faktor profitabilitas juga berpengaruh terhadap kebijakan dividen karena dividen 
adalah laba bersih yang diperoleh perusahaan, oleh karena itu dividen akan dibagikan apabila perusahaan memperoleh keuntungan. Keuntungan yang layak dibagikan kepada pemegang saham adalah keuntungan setelah perusahaan memenuhi kewajiban - kewajiban tetapnya yaitu bunga dan pajak. Pernyataan tersebut didukung oleh penelitian Setiawan (2013), Ali (2015), Jahanzeb (2016), Kangarlouei (2014), Najjar (2009), Yarram (2014), dan Nixon (2012) yang menunjukkan bahwa profitabilitas berpengaruh positif signifikan terhadap kebijakan dividen.

$\mathrm{H}_{2}$ : Profitabilitas berpengaruh positif signifikan terhadap kebijakan dividen pada perusahaan manufaktur yang terdaftar di Bursa Efek Indonesia.

Menurut Suharli dalam Arilaha (2009) perusahaan yang leverage operasi atau keuangannya tinggi akan memberikan dividen yang rendah. Struktur permodalan yang lebih tinggi dimiliki oleh hutang menyebabkan pihak manjemen akan memprioritaskan pelunasan kewajiban terlebih dahulu sebelum membagikan dividen. Perusahaan yang memiliki rasio hutang lebih besar akan membagikan dividen lebih kecil karena laba yang diperoleh digunakan untuk melunasi kewajiban. Hutang jangka panjang diikat oleh sebuah perjanjian hutang untuk melindungi kepentingan kreditor. Kreditor biasanya membatasi pembayaran dividen, pembelian saham beredar, dan penambahan hutang untuk menjamin pembayaran pokok hutang dan bunga. Untuk itu semakin tinggi rasio hutang maka semakin ketatnya perusahaan terhadap perjanjian hutang. Pernyataan tersebut didukung oleh penelitian Kangarlouei (2014), Sari (2015), Mawarni (2014), dan Devi (2014) yang menyatakan bahwa leverage berpengaruh negatif signifikan terhadap kebijakan dividen. 
Ni Wayan Indah Paramyta Agustino, Pengaruh Ukuran Perusahaan...

$\mathrm{H}_{3}$ : Leverage berpengaruh negatif signifikan terhadap kebijakan dividen pada perusahaan manufaktur yang terdaftar di Bursa Efek Indonesia.

\section{METODE PENELITIAN}

Lokasi pada penelitian ini dilakukan pada Perusahaan Manufaktur yang terdaftar di Bursa Efek Indonesia (BEI). Obyek dari penelitian ini adalah variabel yang mempengaruhi Kebijakan Dividen diantaranya : Ukuran Perusahaan, Profitabilitas, dan Leverage pada Perusahaan Manufaktur di Bursa Efek Indonesia.

Ukuran perusahaan dapat dinilai dengahn menggunakan rumuas (Hartono, 2009:379) :

$$
\text { Ukuran Perusahaan }(\text { size })=\operatorname{Ln}(\text { Total Aset })
$$

Dalam penelitian ini diukur dengan menggunakan ROA (Return on Assets). ROA merupakan rasio profitabilitas yang menunjukkan perbandingan antara laba bersih dengan total aktiva perusahaan manufaktur di bursa efek Indonesia tahun 2014 -2016. Satuan yang digunakan dalam ROA adalah persentase dan formulanya dapat dirumuskan sebagai berikut (Wiagustini, 2014:90) :

$$
\text { Return On Assets (ROA) }=\frac{\text { Laba Bersih }}{\text { Total Aktiva }} \times 100 \%
$$

Leverage merupakan rasio yang digunakan untuk mengetahui seberapa besar kemampuan perusahaan dalam membayar seluruh kewajibannya pada Perusahaan Manufaktur di Bursa efek Indonesia tahun 2014 - 2016. Dalam penelitian ini diukur dengan debt to equity ratio. Debt to equity ratio merupakan rasio yang digunakan untuk menilai hutang dengan ekuitas. Leverage dapat dinilai dengan menggunakan rumus : 
Debt to Equity Ratio $(\mathrm{DER})=\frac{\text { Total Kewajiban }}{\text { Total Ekuitas }} \times 100 \%$

Pengukuran kebijakan dividen yang diproksi oleh dividend payout ratio. Dividend payout ratio adalah perbandingan antara dividen yang dibayarkan dengan laba bersih pada Perusahaan Manufaktur yang Terdaftar di Bursa Efek Indonesia tahun 2014 - 2016. Kebijakan dividen dapat dinilai dengan menggunakan rumus (Parica dkk., 2013) :

$$
\text { Dividend Payout Ratio }(\text { DPR })=\frac{\text { Dividen Perusahaan }}{\text { Laba Perusahaan }} \times 100 \%
$$

Metode penentuan sampel yang digunakan dalam penelitian ini adalah sampling jenuh atau sensus. Sampling jenuh atau sensus adalah teknik penentuan sampel bila semua populasi digunakan sebagai sampel. Dengan jumlah populasi 47 perusahaan manufaktur, maka jumlah sampel 47 perusahaan manufaktur yang membayarkan dividen.

Analisis regresi linier berganda digunakan untuk mengukur kekuatan asosiasi (hubungan) linier antara dua variabel atau lebih. Persamaan Regresi Linier Berganda adalah sebagai berikut :

$$
Y=\alpha+\beta_{1} X_{1}+\beta_{2} X_{2}+\beta_{3} X_{3}+\varepsilon
$$

Keterengan :

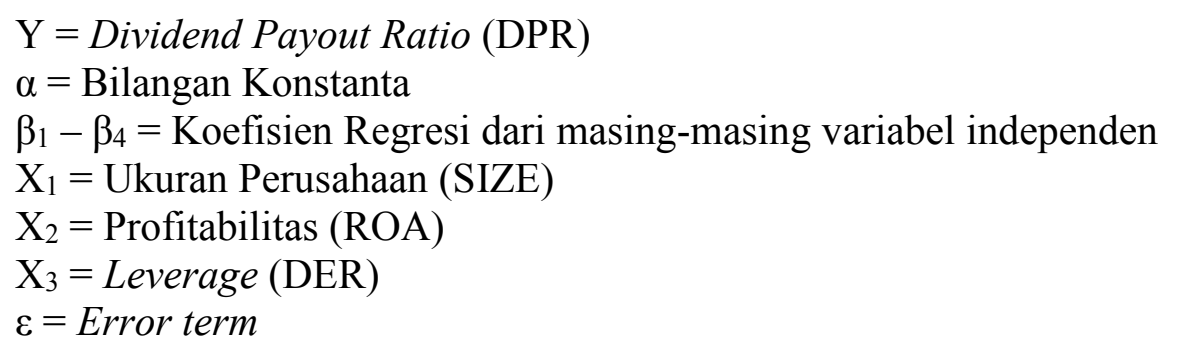

\section{HASIL DAN PEMBAHASAN}


Statistik deskriptif yang digunakan dalam penelitian ini meliputi nilai minimum, maksimum, rata-rata dan standar deviasi yang dapat dilihat pada Tabel 1 berikut:

Tabel 1.

Uji Statistik Deskriptif

\begin{tabular}{lrrrrr}
\hline & N & Minimum & Maximum & \multicolumn{1}{c}{ Mean } & \multicolumn{1}{c}{$\begin{array}{c}\text { Std } \\
\text { Deviation }\end{array}$} \\
\hline SIZE & 141 & 14.44 & 26.29 & 21.2409 & 2.38123 \\
ROA & 141 & .00 & .75 & .1067 & .10403 \\
DER & 141 & .07 & 3.03 & .8048 & .65549 \\
DPR & 141 & .04 & 3.68 & .4405 & .43982 \\
Valid N & 141 & & & & \\
Listwise) & & & & &
\end{tabular}

Berdasarkan Tabel 1. di atas dapat diketahui bahwa jumlah perusahaan manufaktur $(\mathrm{N})$ dalam penelitian ini adalah 141. Hasil analisis statistik deskriptif dapat dijelaskan sebagai berikut:

Ukuran Perusahaan (SIZE) memiliki nilai minimum sebesar 14.44, nilai maksimum sebesar 26.29, dan nilai rata-rata sebesar 21.2409 dengan standar deviasi sebesar 2.38123 .

Profitabilitas (ROA) memiliki nilai minimum sebesar 0.00 , nilai maksimum sebesar 0.75 , dan nilai rata-rata sebesar 0.1067 dengan standar deviasi sebesar 0.10403.

Leverage (DER) memiliki nilai minimum 0.07, nilai maksimum sebesar 3.03, dan nilai rata-rata sebesar 0.8048 dengan standar deviasi sebesar 0.65549.

Kebijakan Dividen (DPR) memiliki nilai minimum 0.04, nilai maksimum 3.68, dan nilai rata-rata sebesar 0.4405 dengan standar deviasi sebesar 0.43982 .

Uji Normalitas bertujuan untuk menguji apakah dalam model regresi, variabel pengganggu atau residual memiliki distribusi normal. Metode yang 
digunakan adalah One Sample Kolmogorov-Smirnov Test. Distribusi data dikatakan normal apabila nilai One Sample Kolmogorov-Smirnov Test $>0,05$, maka data dinyatakan normal.

Tabel 2.

Uji Normalitas

\begin{tabular}{lcc}
\hline & & $\begin{array}{c}\text { Unstandardized } \\
\text { Residual }\end{array}$ \\
\hline $\mathrm{N}$ & Mean & 141 \\
Most Extreme Diferences & Std Deviation & $0 \mathrm{E}-7$ \\
& Absolute & .09447400 \\
& Positive & .112 \\
& Negative & .112 \\
Kolmogorov-Smirniv Z & & -.076 \\
Asymp. SIg (2-tailed) & & 1.328 \\
Sumber: Data diolah, 2018 & & .059 \\
\hline
\end{tabular}

Hasil uji normalitas Kolmogorov-Smirnov Test menunjukkan nilai signifikan sebesar 0,059 lebih besar dari level of signifikan 0,05, sehingga dapat disimpulkan bahwa data berdistribusi normal. Oleh karena itu asumsi normalitas pada regresi telah terpenuhi.

Uji multikolonieritas bertujuan untuk menguji apakah model regresi ditemukan adanya korelasi antar variabel bebas (independen). Model regresi yang baik seharusnya tidak terjadi korelasi antara variabel independen. Untuk mendeteksi ada atau tidaknya multikolonieritas di dalam model regresi dapat dilihat dari nilai Tolerance dan VIF (Variance Inflation Factor). Kedua ukuran ini menunjukkan setiap variabel independen manakah yang dijelaskan oleh variabel independen lainnya. Apabila tolerance $>0,10$ atau nilai $\mathrm{VIF} \leq 10$, ini menunjukkan bahwa tidak terjadi gejala multikolonieritas (Ghozali, 2016:103).

Hasil uji multikoliniearitas menunjukkan bahwa masing-masing variabel bebas memiliki nilai tolerance, yaitu 0,899 (SIZE), 0,936 (ROA) dan 0,955 (DER) 
lebih besar dari 0,10 dan nilai VIF masing-masing variabel bebas tersebut adalah 1,113 (SIZE), 1,068 (ROA) dan 1,048 (DER) lebih kecil dari 10.

Tabel 3.

Uji Multikoliniearitas

\begin{tabular}{lccc}
\hline & & \multicolumn{2}{c}{ Colinearuty Statistic } \\
Model & & Tolerance & VIF \\
\hline & SIZE & .899 & 1.113 \\
& ROA & .936 & 1.068 \\
& DER & .955 & 1.048 \\
\hline
\end{tabular}

Sumber: Data diolah, 2018

Berdasarkan nilai tolerance dan nilai VIF dari masing-masing variabel bebas, maka dapat disimpulkan bahwa tidak terdapat gejala multikolinearitas.

Uji Autokorelasi bertujuan untuk menguji apakah dalam model regresi linear terdapat korelasi antara kesalahan pengganggu pada periode $t$ dengan kesalahan pengganggu pada periode $\mathrm{t}-1$.

Tabel 4.

Uji Autokorelasi

\begin{tabular}{cc}
\hline Model & Durbin-Watson \\
\hline 1 & $1.969^{\mathrm{a}}$ \\
\hline Sumber : Data Diolah,2018 &
\end{tabular}

Hasil uji autokorelasi menunjukkan bahwa nilai Durbin-Watson untuk persamaan regresi adalah 1,969. Nilai du sebesar 1,7685 dengan taraf signifikan 5 persen untuk $n=141$ dan $k=3$. Oleh karena nilai $d w$ dari persamaan tersebut berada pada $\mathrm{du}<\mathrm{dw}<4$-du atau $1,7685<1,969<2,2315$, hal tersebut menunjukkan bahwa tidak terdapat gejala autokorelasi.

Model regresi yang baik adalah yang homokedastisitas atau tidak terjadi Heteroskedasitisitas. Untuk mendeteksi ada tidaknya heteroskedasitisitas dilakukan uji Glejser, yaitu dengan meregresikan nilai absolut variabel terkait dengan variabel bebasnya. Tingkat signifikansi yang digunakan adalah 0,05 . Jika model regresi lebih besar tingkat signifikan yang digunakan maka model regresi tidak 
mengandung gejala heteroskedasitisitas. Sebaliknya jika model regresi lebih kecil tingkat signifikan yang digunakan maka model regresi mengandung gejala heteroskedasitisitas.

Tabel 5.

Uji Heteroskedastisitas

\begin{tabular}{|c|c|c|c|c|c|c|}
\hline & \multirow[t]{2}{*}{ Model } & \multicolumn{2}{|c|}{ Unstandardizes Coeficient } & \multirow{2}{*}{$\begin{array}{c}\text { Standardizes } \\
\text { Coeficient }\end{array}$} & \multirow[t]{2}{*}{$\mathbf{T}$} & \multirow{2}{*}{ Sig } \\
\hline & & B & $\begin{array}{l}\text { Std } \\
\text { Error }\end{array}$ & & & \\
\hline \multirow[t]{4}{*}{1} & (Constant) & -.070 & .161 & & -.437 & .663 \\
\hline & SIZE & .090 & .119 & .067 & .757 & .450 \\
\hline & ROA & -.047 & .155 & -.026 & -.304 & .762 \\
\hline & DER & .079 & .040 & .168 & 1.954 & .053 \\
\hline
\end{tabular}

Sumber: data diolah, 2018

Hasil uji heteroskedastisitas berupa uji glesjer menunjukkan bahwa nilai signifikansi masing-masing variabel bebas lebih besar dari 0,05, sehingga dapat disimpulkan bahwa model regresi dalam penelitian ini tidak terdapat gejala heteroskedastisitas.

Hasil analisis regresi adalah berupa koefisien untuk masing-masing variabel independen.

Tabel 6.

Analisis Regresi Linier Berganda

\begin{tabular}{|c|c|c|c|c|c|c|}
\hline \multicolumn{2}{|c|}{ Model } & \multicolumn{2}{|c|}{ Unstandardizes Coeficient } & \multirow{2}{*}{$\begin{array}{c}\text { Standardizes } \\
\text { Coeficient }\end{array}$} & \multirow[t]{2}{*}{$\mathbf{T}$} & \multirow[t]{2}{*}{ Sig } \\
\hline & & B & $\begin{array}{c}\text { Std } \\
\text { Error }\end{array}$ & & & \\
\hline \multirow[t]{4}{*}{1} & (Constant) & -.47 & .232 & & -1.881 & .062 \\
\hline & SIZE & .396 & .172 & .193 & 2.304 & .023 \\
\hline & ROA & .765 & .225 & .279 & 3.407 & .001 \\
\hline & DER & .072 & .058 & .100 & 1.233 & .220 \\
\hline
\end{tabular}

Sumber: Data diolah, 2018

Berdasarkan Tabel 6. di atas dapat diketahui persamaan regresi linier berganda sebagai berikut:

$$
\mathrm{DPR}=-0,437+0,395 \mathrm{SIZE}+0,765 R O A+0,072 \mathrm{DER}
$$


Persamaan regresi linier berganda dapat diuraikan sebagai berikut. Nilai Konstanta sebesar -0,437 artinya apabila ukuran perusahaan (SIZE), profitabilitas (ROA) dan leverage (DER) sama dengan 0 maka DPR sebesar -0,437.

Nilai koefisien regresi variabel ukuran perusahaan (SIZE) sebesar 0,396, hal ini memiliki arti apabila ukuran perusahaan mengalami peningkatan sebesar 1 satuan dengan asumsi profitabilitas dan leverage sama dengan 0 maka DPR akan meningkat sebesar 0,396 .

Nilai koefisien regresi variabel profitabilitas (ROA) sebesar 0,765 , hal ini memiliki arti apabila profitabilitas mengalami peningkatan sebesar 1 satuan dengan asumsi ukuran perusahaan dan leverage sama dengan 0 maka DPR akan meningkat sebesar 0,765 .

Nilai koefisien regresi variabel leverage (DER) sebesar 0,072, hal ini memiliki arti apabila profitabilitas mengalami peningkatan sebesar 1 satuan dengan asumsi ukuran perusahaan dan profitabilitas sama dengan 0 maka DPR akan meningkat sebesar 0,072 .

Hasil uji koefisien determinasi $\left(\mathrm{R}^{2}\right)$ disajikan pada Tabel 7 berikut:

Tabel 7.

Uji Koefisien Determinasi $\left(R^{2}\right)$

\begin{tabular}{lllll}
\hline Model & $\mathbf{R}$ & R Square & $\begin{array}{l}\text { Adusted R } \\
\text { Square }\end{array}$ & $\begin{array}{l}\text { Std. Error of The } \\
\text { Estimate }\end{array}$ \\
\hline 1 & $.374^{\mathrm{a}}$ & .140 & .121 & .09550 \\
\hline Sumber: Data diolah, 2018 & & &
\end{tabular}

Hasil uji koefisien determinasi $\left(\mathrm{R}^{2}\right)$ menunjukkan bahwa nilai Adjusted $R$ Square sebesar 0,121 hal ini berarti 12,1\%. Nilai tersebut berarti bahwa perubahan yang terjadi pada DPR dapat dijelaskan oleh variabel ukuran perusahaan, 
profitabilitas, dan leverage sebesar $12,1 \%$, hal ini berarti $87,9 \%$ dijelaskan oleh faktor lain diluar penelitian.

Kriteria signifikansi simultan adalah jika nilai signifikansi $\mathrm{F}<0.05$, maka $\mathrm{H} 0$ ditolak, artinya terdapat pengaruh yang signifikan antara semua variabel independen terhadap variabel dependen.

Tabel 8.

Uji F (Uji Signifikan Simultan)

\begin{tabular}{lllllll}
\hline Model & & $\begin{array}{l}\text { Sum of } \\
\text { Squares }\end{array}$ & Df & $\begin{array}{l}\text { Mean } \\
\text { Square }\end{array}$ & F & Sig \\
\hline 1 & Regression & .203 & 3 & .068 & 7.424 & $0.000^{\mathrm{b}}$ \\
& Residual & 1.250 & 137 & .009 & & \\
& Total & 1.453 & 140 & & & \\
\hline
\end{tabular}

Sumber: Data diolah, 2018

Hasil uji F (uji signifikan simultan) menunjukkan bahwa diperoleh $F_{\text {hitung }}$ sebesar 7,424 dengan signifikan $0,000<0,05$ maka model regresi bisa dipakai untuk memprediksi SHU. Maka dapat disimpulkan bahwa variabel bebas yang terdiri dari ukuran perusahaan, Profitabilitas dan leverage total aset secara bersama-sama (simultan) berpengaruh signifikan terhadap variabel terikat yaitu kebijakan deviden.

Berdasarkan Tabel 6. dapat dijelaskan bahwa Variabel ukuran perusahaan (SIZE) terhadap kebijakan deviden (DPR) menunjukan nilai signifikansi sebesar 0,023 dan nilai $\mathrm{t}$ hitung sebesar 2,304 yang artinya bahwa nilai signifikansi ukuran perusahan (SIZE) lebih kecil dari 0,05 sehingga $\mathrm{H}_{1}$ diterima, artinya bahwa ukuran perusahaan (SIZE) berpengaruh positif terhadap perolehan kebijakan deviden. Hal ini menunjukkan bahwa semakin besar ukuran perusahaan maka semakin besar pula dividen yang akan dibagikan. 
Ni Wayan Indah Paramyta Agustino, Pengaruh Ukuran Perusahaan...

Pengaruh variabel profitabilitas (ROA) terhadap kebijakan dividen (DPR) menunjukan nilai signifikansi 0,001 dan nilai t hitung sebesar 3,407 yang artinya bahwa nilai signifikansi profitabilitas (ROA) lebih kecil dari 0,05 sehingga $\mathrm{H}_{2}$ diterima, artinya bahwa profitabilitas (ROA) berpengaruh positif terhadap kebijakan dividen (DPR). Hal ini menunjukkan bahwa meningkatnya profitailitas maka semakin besar pula dividen yang akan dibagikan.

Pengaruh variabel leverage (DER) terhadap kebijakan dividen (DPR) menunjukan nilai signifikansi 0,220 dan nilai t hitung sebesar 1,233 yang artinya bahwa nilai signifikansi leverage (DER) lebih besar dari 0,05 sehingga $\mathrm{H}_{3}$ ditolak, artinya leverage (DER) tidak berpengaruh terhadap kebijakan dividen (DPR).

Hipotesis pertama $\left(\mathrm{H}_{1}\right)$ ukuran perusahaan berpengaruh positif terhadap kebijakan dividen. Berdasarkan pengujian hasil analisis regresi uji t diperoleh nilai koefisien regresi ukuran perusahaan 0,396 dengan nilai signifikansi 0,023 lebih kecil dari 0,05 . Hasil dari penelitian ini menunjukan bahwa ukuran perusahaan berpengaruh positif terhadap kebijakan dividen pada Perusahaan Manufaktur yang Terdaftar di Bursa Efek Indonesia periode 2014-2016 yang berarti hipotesis pertama diterima, dan mendukung penelitian dari Kangarlouei (2014), Najjar (2009), Jape (2016), Yarram (2014), dan Nixon (2012) mengemukakan bahwa ukuran perusahaan berpengaruh positif signifikan terhadap kebijakan dividen.

Hal ini menunjukan bahwa semakin meningkatnya ukuran perusahaan maka akan semakin meningkat dividen yang dibagikan. Karena semakin besar ukuran perusahaan semakin mudah untuk mendapatkan modal eksternal dalam jumlah 
yang lebih besar terutama dari hutang. Ukuran perusahaan merupakan simbol ukuran perusahaan yang berhubungan dengan peluang dan kemampuan untuk masuk ke pasar modal dan jenis pembiayaan eksternal lainnya yang menunjukkan kemampuan meminjam.

Hipotesis kedua $\left(\mathrm{H}_{2}\right)$ profitabilitas berpengaruh positif terhadap kebijakan dividen. Berdasarkan uji $\mathrm{t}$ diperoleh nilai koefisien regresi profitabilitas 0,765 dengan signifikansi 0,001 lebih kecil dari 0,05. Hasil dari penelitian ini menunjukan bahwa profitabilitas berpengaruh positif terhadap kebijakan dividen pada Perusahaan Manufaktur yang Terdaftar di Bursa Efek Indonesia periode 2014-2016 yang berarti hipotesis kedua diterima, dan mendukung penelitian dari Setiawan (2013), Ali (2015), Jahanzeb (2016), Kangarlouei (2014), Najjar (2009), Yarram (2014), dan Nixon (2012) yang menunjukkan bahwa profitabilitas berpengaruh positif signifikan terhadap kebijakan dividen. Hal ini menunjukan bahwa semakin besar profitabilitas maka akan semakin meningkat dividen yang dibagikan. Faktor profitabilitas juga berpengaruh terhadap kebijakan dividen karena dividen adalah laba bersih yang diperoleh perusahaan, oleh karena itu dividen akan dibagikan apabila perusahaan memperoleh keuntungan.

Hipotesis ketiga $\left(\mathrm{H}_{3}\right)$ leverage berpengaruh negatif terhadap kebijakan dividen. Berdasarkan uji t diperoleh nilai koefisien regresi leverage 0,072 dengan nilai signifikansi 0,220 lebih besar dari 0,05. Dari persamaan regresi diketahui bahwa leverage berhubungan positif terhadap kebijakan dividen pada Perusahaan Manufaktur yang Terdaftar di Bursa Efek Indonesia periode 2014-2016 yang berarti hipotesis ketiga ditolak. 
Dimana DPR atau leverage yang dihitung dengan membandingkan kewajiban dengan ekuitas diperoleh hasil bahwa ekuitas atau modal yang dimiliki masih lebih besar dari kewajiban. Hal ini menunjukkan jika ekuitas/modal lebih besar dari kewajiban sehingga perusahaan mampu memenuhi kewajiban untuk membayar utang jangka panjang/pendek termasuk juga membagikan dividen terhadap investor, namun dengan signifikansi yang lebih besar 0,05 dengan derajat kepercayaan $95 \%$ pengaruh positif yang diperoleh tidak signifikan berarti tingginya tingkat leverage tidak mempengaruhi DPR secara keseluruhan. Hal ini tidak sesuai dengan penelitian yang diperoleh Sari (2015), dan Mawarni (2014) yang menyatakan bahwa leverage berpengaruh negatif terhadap kebijakan dividen, namun yang diperoleh Arilaha (2009) dan Tahir (2015) yang menyatakan bahwa leverage berpengaruh negatif tetapi tidak signifikan terhadap kebijakan dividen.

\section{SIMPULAN}

Ukuran perusahaan berpengaruh positif signifikan terhadap kebijakan dividen pada Perusahaan Manufaktur yang Terdaftar Di Bursa Efek Indonesia Periode 2014-2016. Hal ini menunjukan bahwa semakin meningkatnya ukuran perusahaan maka akan semakin meningkat dividen yang dibagikan.

Profitabilitas berpengaruh positif signifikan terhadap kebijakan dividen pada Perusahaan Manufaktur yang Terdaftar Di Bursa Efek Indonesia Periode 20142016. Hal ini menunjukan bahwa semakin besar profitabilitas maka akan semakin meningkat dividen yang dibagikan.

Leverage berhubungan positif dan tidak berpengaruh signifikan terhadap kebijakan dividen pada Perusahaan Manufaktur yang Terdaftar Di Bursa Efek 
Indonesia Periode 2014-2016. Hal ini menunjukkan bahwa semakin meningkatnya leverage maka akan meimgkatnya dividen yang dibagikan.

Sampel penelitian dalam penelitian ini adalah pada Perusahaan Manufaktur di Bursa Efek Indonesia. Untuk penelitian selanjutnya diharapkan dapat menambah perusahan lain dalam penelitian tidak hanya menggunakan peusahaan manufaktur.

Variabel dalam penelitian ini adalah ukuran perusahaan, profitabilitas dan leverage. Untuk penelitian selanjutnya disarankan untuk mengembangkan dan menambah variabel-variabel yang dapat mempengaruhi kebijakan dividen.

\section{REFERENSI}

Benerjee, Souvik. (2016). Determinants of Dividend Policy for SelectedInformationTechnology Companies in India : An Empirical Analysis.Parikalpana - KIIT Journal of Management.12. (1) : 1-15

Hanafi, Mamduh M dan Abdul Halim. (2005). Analisis Laporan Keuangan, Edisi Kedua, Yogyakarta : STIE YKPN.

Handayani, D.R. \& Hadinugroho, B. (2009). Analisis Pengaruh KepemilikanManajerial, Kebijakan Hutang, ROA, Ukuran Perusahaan terhadapKebijakan Divide. Jurnal Fokus Manajerial.7. (1). 64-71.

Ikhsan, Arfan. (2009). “Akuntansi Manajemen Perusahaan Jasa”. Edisi Pertama. Graha Ilmu.Yogyakarta.

Jape, Smita. (2016). Study and Analysis of Dividend Policies, Practice and its Application in Mumbai Based Corporate Houses. International Journal of Financial Management. 6. (4). : 34-48

Kangarlouei, Saeid Jabbarsadeh. (2014). Life - Cycle Theory, Free Cash Flow and Dividend Policy In Frims Listed In Tehran Stock Exchange. Journal of Commerce \& Accounting Research. 3. (1) : 1-17

Kasmir. (2009). “Analisis Laporan Keuangan”. Jakarta: Rajawali Pers.

Khalid, Sania. (2015). Determination of Factors effecting the Dividend policy of Organizations. International Journal of Information, Business and Management.7. (3) : 22-34 
Mawarni, Luh Fajarini Indah \& Ni Made Dwi Ratnadi. 2014. Pengaruh Kesempatan Investasi, Leverage, Dan Likuiditas Pada Kebijakan Dividen Perusahaan Manufaktur Yang Terdaftar Di BEI. E-Jurnal Akuntansi Universitas Udayana. 9. (1) : 200208.

Najjar, Basil Al. (2009). Dividend Behaviour And Smoothing New Evidence From Jordanian Panel Data. Studies in Economics and Finance. 26. (3) : 182-197.

Nixon, William R and Bacon Frank. (2012). Debt and Dividend Decusions : Stock Vs Non Stock Firms. Journal of Business and Behavioral Sciences. 24. (3) : 25-38

Parica, Roni. (2013). Pengaruh Laba Bersih, Arus Kas Operasi, Likuiditas, dan Profitabilitas terhadap Kebijakan Dividen Pada Perusahaan Automotive and Allied Product yang terdaftar di BEI. Jurnal Akuntansi Universitas Riau. 2. (1) : 1-17

Rodoni, Ahmad \& Herni Ali. (2010). "Manajemen Keuangan". Edisi Pertama, Jakarta: Mitra Wacana Media.

Sari, Komang Ayu Novita dan Luh Komang Sudjarni. (2015). Pengaruh Likuiditas, Leverage, Pertumbuhan Perusahaan, Dan Profitabilitas Terhadap Kebijakan Dividen Pada Perusahaan Manufaktur Di BEI. E-JurnalManajemen Unud. 4. (10) : 3346 - 3374

Setiawan, Doddy and Phua Lian Kee. (2013). Corporate Governance and Dividend Policy in Indonesia. Business Strategy Series. 14. (5) : 67-78

Shubiri, Faris Nasif AL. (2012). The Relationship between Ownership Structure and Dividend Policy: An Empirical Investigation. Review of International Comparative Management. 13. (4) : 54-68

Sundjaja, Ridwan \& Inge Barlin. (2010). “Manajemen Keuangan”. Edisi 6. Jakarta: Literata Lintas Media.

Wiagustini, Luh Putu. (2014). Manajemen Keuangan Denpasar : Udayana University Press.

Yarram, Subba Reddy and Brian Dollery. (2014). Corporate Governance And Financial Policies (Influence Of Board Characteristics On The Dividend Policy Of Australian Firms). Managerial Finance. 41. (3) : 267-285 